\title{
An Analysis on Risale-I Aruz of Babur*
}

\author{
Mayisguli Wusuyin \\ School of Uygur Language and Culture \\ Northwest Minzu University \\ Lanzhou, China 730030
}

\author{
Ayiguli Tuersunniyazi \\ School of Uygur Language and Culture \\ Northwest Minzu University \\ Lanzhou, China 730030
}

\begin{abstract}
Between the beginnings of the 11th century to the beginning of the 20th century, poetic works occupied an important position in the history of Uygur literature. In order to better research classical Uygur literature, scholars must master the relevant theory and research method of poetics. In the history of classical Uygur literature, Nawayi, Babur and other poets and literati created theoretical works about poetic aspects. Among them, Babur's Risale-I Aruz was one of the most important works in the research of Chaghatay literature. This paper mainly introduces the research status of the book of Risale-I Aruz at home and abroad, and the practical application value and academic value of the work research.
\end{abstract}

Keywords—Babur; Risale-I Aruz; research; significance

\section{INTRODUCTION}

From ancient times till today, poets have attached great importance to the meter, rhythm and its practical application in their creation. In particular, ancient poets were not only adept at writing poetry, but also had solid professional knowledge in poetic theory. Therefore, to understand the characteristics of ancient poets' poetic creation, it is very important to understand the relevant works in this respect. Because there are very few introductions and researches on Babur's book of Risale-I Aruz in China, in order to give rise to the interest and attention of researchers engaged in Chaghatay language and literature, the author briefly introduces Babur's book of Risale-I Aruz and explores its academic significance through this paper.

\section{BABUR'S LIFE AND HIS WORKS}

Zahiruddin Muhammed Babur (1483-1530) was born in Ferghana, Central Asia (now Uzbekistan), and succeeded the Ferghana throne in 1494 at the age of 47 . He was a king and literati in the history of Central Asia. He was a founding monarch of the Mughal Empire that ruled the Indian subcontinent, who is the sixth grandson of Timur of the Timur Empire, and his name "Babur" means "tiger". He captured Samarkand in 497, who was defeated by Uzbeks in 1501 and fled to Kabul. In 1510, he was defeated and killed in Muhammad shay-bani khan. Babur seized the opportunity to ally himself with the Persian Safavid Empire and fought back to Samarkand. Because of without the support of the

*This paper is a phased achievement of the central university special fund project of Northwest Minzu University of the first-level discipline of "Chinese language and literature" --Arrangement and Analysis of Babur Works (Risale-I Aruz manual) (31920180018) and Uygur Literature Research of Chaghatay (319201808112). people, Babur once again retreated to Kabul, and entered North India in 1519. During the battle of Panipat in 1526, he defeated the Sultan Army in Delhi, and defeated the allied forces of Indian feudal princes in the west of Agra in 1527. In 1529, he defeated the Afghan leader of Haar in Patna, and finally established the Mughal Empire ${ }^{1}$

During his lifetime, he created Babur Memoirs, Babur Poetry Anthology, Risale-I Aruz, Mubaiyan, Book of Pilgrimage, Book of Worship and etc. Among them, Babur Memoirs was a monumental work with practical application value and academic value to research the history of Central and South Asia, Chaghatay and literature. Risale-I Aruz was a work with very important place in the research of Chaghatay's poetic meter after Alihill Nawayi's works. The Babur Poetry Anthology was one of the works reflecting poetic style of Babur. From his lifetime, we can see that he was not only a king, but also a poet, historian and literary critic with great literary talent.

\section{THE DOMESTIC RESEARCH STATUS OF BABUR'S WORKS}

It is understood that Turkey, Uzbekistan, Afghanistan, France, Russia and other countries have collected manuscripts of Babur's relevant works. All the works of Babur have been carried out lots of works research from the perspective of historiography, philology, linguistics, literature, and at the same time, papers have been published.

Since the 1980s, domestic scholars have sorted out, announced and published Babur Memoirs and announced the Selection of Babur Poetry Anthology. For example, Mr. Wang Zhilai translated the Russian version of Babur Memoirs into Chinese that was published by the Commercial Press in 1997; Professor Hamit Timur collated and published the Turkic transcript of Babur Memoirs in Chaghatay, and the Uygur version of the work was published by the Nationalities Publishing House in 1992.

Other literary works of Babur are published in various Uyghur journals in the form of scatter. Up to now, Babur's works such as Babur Poetry Anthology, Book of Pilgrimage and Book of Worship have not been published in China.

However, there is no systematic research of the published works and scatteredly published works.

https://baike.baidu.com/item/Babur/1185836?fr=aladdin 


\section{CuRrent Situation OF OVERSEAs RESEARCH}

Since the 18th century, European scholars began to research Babur's works, especially historians began to publish and collate Babur Memoirs. It is understood that at present this work has been officially published in English, German, Russian, Chinese, Kazakh, Uzbek, Uyghur, Persian, Japanese, Turkish and other translations. However, no scholars from other countries have specially researched the work of Risale-I Aruz except Russian, Uzbek and Turkish scholars.

It is understood that foreign scholars from especially Turkey, Japan, Uzbekistan, Muscovy and the United States have collated and published Babur's works, and have done a large number of researches on his works from the perspectives of philology, linguistics, literature and history. For example, Babur Memoirs that was collated by Resid Rahmeti ARAT was published by Turkish Historical Association Press in 2000; Babur Poetry Anthology that was collated by Bilal Yücel was published by Ataturk Cultural Research Center of Turkey in 1995 and linguistic researches were conducted; Babur's Manual of Parents was collated and published by Ali Fuat Bilkan; Tanju Oral Seyhan collated and published the Babur's work of Explanation of Teaching Methods and conducted linguistic researches in 2004. In Japan, Eiji Mano collated and published a revised version of original text of Babur Memoirs in 199 and 1996, and conducted researches on it from the perspectives of linguistics, historiography and toponymy.

In the United States, the English version of Babur Memoirs translated by Annette Susannah was published in Washington in 1922; the English version of Wheeler M. Thackston was published by Harvard University Press in 2002.

In Muscovy, the revised version of the original text of Babur Memoirs collated by Elminiski in 1857 was published in Kazan.

In Uzbekistan, the Book of Pilgrimage collated by Edward Saidbeg Hasan in 1993 was published by the People's Heritage Press with the name of Abdullah Kadige; And the Babur Memoirs, collated by Parsa Shamisye, was published by the Little Star Press in 1989.

It can be seen from this that literary works of Babur have not yet received a more comprehensive publishing opportunity in China or abroad, and at the same time there are no scientific research teams specializing in the research of Babur's works.

\section{TRANSCRIPT OF RISALE-I ARUZ AND ITS PUBLICATION AND ANNOUNCEMENT}

In the field of ancient literature research, the original or manuscript of works is very important, which is because it is difficult to avoid mistakes in modern language translation without providing the works of ancient literature written by original text. Therefore, the research of Babur's Risale-I Aruz must also attach importance to the original text of the work.
It is understood that there are two versions of Babur's Risale-I Aruz. Among them, one version scribal by Haji Muhammed Samarqandi in 1533 is currently collected in the French National Library. Another copy is collected in the old library of Li-Tan Su, Tehran, Iran. ${ }^{2}$

Edward Said Buick Hasan, a Babur scholar in Uzbekistan, has collated and published Babur's work of Risale-I Aruz (Muchekhtarsar). This work was published in Uzbek by Uzbekistan Science Press in 1971 with a total of 240 pages, including introduction, text and photocopy.

In 1972, Stebilewa, a Russian orientalist, published Babur's book of Risale-I Aruz in the name of Traktat $\mathrm{Ob}$ Aruze. In this book, Ms. Stebilewa gave a detailed introduction to the significance of the work, introduced one by one the terminology related to the Risale-I Aruz, and provided a photocopy of the Risale-I Aruz.

In addition, such scholars from various countries as R. Nour, E. Blochet, M.Mehmet Fuat Koprulu, I. W. Stebliwa, Shelbuck, Halide Ehmede and Tanju Ural Saihan published academic papers concerning Risale-I Aruz from 1930 to 2005 .

In the aspect of the research of Chaghatay literature, Nawayi's work of Criteria of Meter and Babur's work of Risale-I Aruz are indispensable to scholars, which is because these two works are all works introducing the literary and poetic meter of Chaghatay. Before that, many poets had adopted works about Arab-Persia Risale-I Aruz. At the same time, they applied many prosodic styles in their poetic works, and did not summarize the Aruz theory which was conforming to the linguistic features. In the era of Nawayi and Babur, these two poets filled in the blank in this respect and provided new theoretical research works for litterateurs.

From Babur's literary and historical works, we can see that Babur has mastered the knowledge of poetic theory, and at the same time he has a certain literary and artistic view. From Babur Memoirs, he mentioned Nawayi, a classical Chaghatay poet, and some of his works. For example, "AliLost Son-Burke is a unique person. Since he wrote poems in Turkic, no one has written so much and so well compared with him. He wrote six collections of poems... He also wrote a book on poetic technique, which is entitled Mizanu'l avzan. There were many places to be blamed in this book; among which, four of the 24 rhythms of Joubais (quatrains) were wrong; and there were also mistakes in talking about other rhythms. Anyone who pays attention to the prosody knows about it. $^{3}$

In short, we can say that the preceding part of the text can reflect Babur's literary creation and literary theory level. When Babur evaluated a poet, he did not have subjective factors to describe the shortcomings of other writers, but expounded his views on other writers and works according to the theoretical knowledge that he grasped.

\footnotetext{
2. Bilal Yücel, Babür Divanı, Atatürk Kültür Merkezi, P17, Ankara,

Babur: Babur Memoirs (translated by Wang Zhilai). Commercial Press, 1997, P. 268-269.
} 


\section{The PRACTICAL SignificANCE OF RisALE-I ARUZ IN UYGUR LITERATURE}

In the literary creation of Uyghur nationality, poetry occupies a large proportion of classical literature. Although modern literature has made great progress in genre, poetry still occupies a very prominent position. With the enhancement of cultural exchanges among different nationalities, more and more readers will appreciate Uyghur poetry by Chinese. Therefore, it may be conducive to readers to discuss the meter and forms of Uyghur poetry and introduce some knowledge in this respect. ${ }^{4}$ Therefore, the author believes that the significance of the study of this work is as follows:

Firstly, from the perspective of form, content and the relationship between them, this paper systematically describes the classification of Babur's works, tries to summarize the classification of Babur's works, its position in classical poetry and biography, and researches and analyses the relationship between form and content, and the influence of society on Babur's creation. The proportion in Uygur classical literature really occupies an important position. However, many scholars have made some achievements in the aspect of content analysis and comparative research, but the research on the form and poetic style classification of classical poetry is not deep enough. In classical Uygur poetics, we can see the poetic style classification such as double-line poems, terza rima, quatrian, cinquain, hexastich, ode poems and Ghazal (lyric poems).

Secondly, from the perspective of metrics and phonetics, this paper summarizes the status of Babur's Risale-I Aruz in classical Uygur poetics. The characteristics and classification of metrics used in classical Uygur poetry, especially the attempt to analyze and summarize the use of Aruz metrics in classical Uygur poetics, and its changing process with the times, analyze the reasons and summarize the characteristics of the use of Aruz metrics in different times. The form of Arabic-Persian poetry has also brought some changes to the traditional Uygur poetry. Aruz metrics in Arabic-Persian poetry appear in traditional Uygur poetry, so the metrics of Uygur poetry have been further improved and developed. There are two opinions on the question of metrics in Uygur poetics. A group of scholars believe that the Aruz metrics in classical Uygur poetics is inherent, not borrowed from ArabPersian literature. On the contrary, another group of scholars believe that only Barmark's metrics (syllable metrics) is used in classical Uygur poetics, and Aruz metrics was used in Turkic national literary poetry under the influence of ArabPersian literature after the ancient Turks believed in Islam. Through this work, we can summarize, analyze and research this issue from the perspective of linguistics and metrics, and find the metrical and prosodic features of classical Uygur poetics.

Thirdly, Babur attached great importance to the use of language in both poetic works and prose works. Especially, he carefully considered the match of words and avoided the

\footnotetext{
4 Zhang Hongchao: The Rhythm and Forms of Uyghur

Poetry.Xinjiang Social Sciences, No. 1, 1987, p.109
}

repetition of words in Babur Poetry Anthology and Risale-I Aruz. By the research of Risale-I Aruz, we can understand the linguistic characteristics of Babur.

Fourthly, through the research of Babur's Risale-I Aruz, we will find out Alihill Nawayi and Babur's views and explanations on Aruz metrics.

\section{CONCLUSION}

In short, the author introduces Babur's life and his works and the research condition of Babur Memoirs and Risale-I Aruz at home and abroad through this paper, with focusing on the exploration and analysis of the research condition of Risale-I Aruz overseas, Babur's literary and artistic views, and the practical application and academic value of Risale-I Aruz in the research of ancient Uygur literature. Although this paper has short length on the one hand and is not very profound on the other hand, I believe that it can attract the attention of domestic scholars in this respect, and it will fill the blank in our future study and research.

\section{REFERENCES}

[1] Babur: Babur Memoirs (translated by Wang Zhilai), Commercial Press, 1997. (in Chinese)

[2] Babur: Babur Memoirs (Arrangement and Publish by Hamidi Timur, Uygur edition, Nationalities Publishing House, 1992). (in Chinese)

[3] Mahmud Kashgariy: Great Turkic Dictionary, Xinjiang People's Publishing House, 2008. (in Chinese)

[4] Yusu Has Hajib: Fule Wisdom, Xinjiang Science and Technology Publishing House, 2006. (in Chinese)

[5] Mu Hongyan: Research on Classical Persian Poetics. Kunlun Publishing House, 2011. (in Chinese)

[6] Zamir Saidura: Aruz Metrics Theory. Xinjiang University Press, 2011 (in Chinese)

[7] Aggi Aihemaiti, On Uygur Poetry, Nationalities Publishing House, 1982. (in Chinese)

[8] Edited by the Twelve Mukams Research Society of Xinjiang Uygur Autonomous Region and the Classical Literature Research Society of Xinjiang Uygur Autonomous Region: Twelve Mukams of Uygur Autonomous Region (1-13), China Encyclopedia Press, 1997. (in Chinese)

[9] Twelve Mukams of the Cultural Department of Xinjiang Uygur Autonomous Region: Twelve Mukams, Music Publishing House, Nationalities Publishing House, 1960. (in Chinese)

[10] Geng Shimin, Ancient Uygur Poetry Selection, Xinjiang People's Publishing House, 1982. (in Chinese)

[11] Li Guoxiang: Collected Works of Li Guoxiang, China Literary Federation Press, 2004 (in Chinese)

[12] Editor-in-chief of Abduk Remu Rehman, History of Uygur Literature, Xinjiang University Press, 1998. (in Chinese)

[13] Zhang Hongnian, History of Persian Literature, Kunlun Publishing House, 2003. (in Chinese)

[14] Edited by Research of Ethnic Literature of Xinjiang Academy of Social Sciences: History of Uygur Literature (1-4), Ethnic Publishing House, 2006. (in Chinese)

[15] Li Guoxiang, History of Uygur Literature, Lanzhou University Press, 1992. (in Chinese)

[16] Edited by Xinjiang People's Publishing House, Selected Works of Classical Uygur Literature, Xinjiang People's Publishing House, 1984. (in Chinese)

[17] Lang Ying: Fule Wisdom and Eastern and Western Culture, Xinjiang People's Publishing House, 1992. (in Chinese) 
[18] Zamu Dirichin: Knowledge of Turkish Poetry, Ankara, 2009.

[19] R. Arat, Ancient Turkic Poetry, Ankara 1991.

[20] R. Selcuk Uysal: Rhetoric and Literary Dictionary, Istanbul 2010.

[21] V.V. Baartorde: Turkism and Shamanism, Istanbul, 2009.

[22] Ahmet Cevdet Pasa: Ottoman Literary Rhetoric, Akcag, Ankara 2000.

[23] Alishir Nawayi: Standards of Metrics, Ankara 1993.

[24] N. Melarjef: Uzbek Literature (1-3), Tashkent, 1965.

[25] Babur: Babur Memoirs (published by R. Alat), Kabalci, Istanbul, 2006. 